\title{
ANALIZA ZVUČNIH OKOLINA - PUT PREMA UGODNIJOJ I USPJEŠNIJOJ RADNOJ SREDINI
}

UDK 534:331.45

PRIMLJENO: 17.12 .2018$.

PRIHVAĆENO: 14.6 .2019

Ovo djelo je dano na korištenje pod Creative

Commons Attribution 4.0 International License

SAŽETAK: Koncept zvučnih okolina uveden je kako bi se izmijenila i nadopunila procjena buke i njezinih utjecaja na čovjeka. Istraživanje zvučnih okolina predlaže pomalo drugačiji pristup istraživanju buke uzimajući u obzir njezinu složenost i multidisciplinarnost. Stoga istraživanje zvučnih okolina nije istraživanje same buke, već uvjeta i razloga njezinog nastanka, razine opažanja i procjene, prvenstveno od strane čovjeka odnosno ljudi. Jedna zvučna okolina obuhvaća određeni okoliš odnosno sredinu, a samim time i veliki broj zvučnih izvora čije karakteristike utječu na uobičajene čovjekove aktivnosti, njegovu koncentraciju i raspoloženje. S obzirom da ljudi danas većinu vremena provedu na poslu, poželjno je da su im radne okoline ugodne i s akustičkog aspekta kako bi zaposlenici bili što zadovoljniji i uspješniji u izvršavanju radnih zadataka. Ovaj rad u tom smislu diskutira utjecaj četiriju radnih zvučnih okolina na čovjeka. One su redom: dječji vrtić, dionica autoputa, industrijska hala i trgovački centar. Ove četiri okoline su odabrane jer su generalno percipirane kao stresne za svoje zaposlenike.

Ključne riječi: zvučna okolina, soundwalk metoda, radna okolina, upitnik, zadatak

\section{ZVUČNA OKOLINA}

Koncept zvučnih okolina uveden je kako bi se izmijenila i nadopunila procjena buke i njezinih učinaka na čovjeka. Jedna zvučna okolina (engl. Soundscape) prema definiciji obuhvaća određeni okoliš odnosno sredinu, a samim time i veliki broj zvučnih izvora čije karakteristike utječu na uobičajene čovjekove aktivnosti, njegovu koncentraciju i raspoloženje (Schafer, 1994.).

Zvučnu okolinu određene sredine čine razne skupine zvukova. One se mogu podijeliti u tri velike skupine: biofonija, geofonija i antrofonija (Schafer, 1994., Krause, 2008.). Biofoniju čine svi zvukovi koje proizvode živi organizmi u svojem prirodnom staništu (Tablica 1); (Krause,

*Dr. sc. Mia Suhanek, (mia.suhanek@fer.hr), prof. dr. sc. Ivan Đurek, (ivan.djurek@fer.hr), dr. sc. Sanja Grubeša, (sanja.grubesa@ fer.hr), izv. prof. dr. sc. Antonio Petošić, (antonio.petosic@fer.hr), Sveučilište u Zagrebu, Fakultet elektrotehnike i računarstva, Zavod za elektroakustiku, Unska 3, 10000 Zagreb.
2008.). Ona je daleko najkompleksnija odlika zvučnih okolina jer ju objedinjuju svi biološki zvučni izvori, od onih mikroskopskih do velikih fauna, koji obitavaju u određenom okolišu tijekom određenog razdoblja. U okolišima koji su bogati različitim glasovima živih bića, organizmi proizvode akustičke signale u različitim prostornim odnosima te mogu činiti jedan zvučni događaj ili više njih. Geofonija su svi prirodni zvukovi koji dopiru iz nebioloških izvora u određenom okolišu (Tablica 1). Generalno, oni se mogu podijeliti na četiri vrste: zvučni efekti vjetra, vode, klimatskih obilježja i geofizičkih sila. Antrofonija su svi zvukovi generirani od strane čovjeka u bilo kojem prirodnom okolišu. $U$ tu skupinu ubraja se razgovor ljudi, glazba, ali i buka prometa.

Iz navedenog nameće se zaključak da je koncept zvučne okoline kao područje istraživanja iznimno široko te zahtijeva multidisciplinarni pristup. U studijama i istraživanjima, osim aku- 
stičkih inženjera, sudjeluju psiholozi, liječnici, građevinari, arhitekti i sociolozi.

Tablica 1. prikazuje zvučne izvore ili akustičke komponente te izravne akustičke učinke neantropogenih zvučnih elemenata (biofonija i geofonija).

\section{Tablica 1. Karakteristike neantropogenih} zvučnih elemenata

Table 1. Characteristics of non-anthropogenic sound elements

\begin{tabular}{||l||}
\hline \hline Vrijeme \\
\hline S: vjetar, kiša, grmljavina, potresi, oblaci \\
\hline $\begin{array}{l}\text { D: stvaranje zvuka, širenje zvuka, apsorpcija, refleksija, } \\
\text { refrakcija, difuzija, difrakcija, maskiranje }\end{array}$ \\
\hline Životinje \\
\hline $\begin{array}{l}\text { S: glasanje životinja: ptice, sisavci, kukci, reptili, vodozemci; } \\
\text { kretanje životinja: trčanje, letenje, skakanje, slijetanje; } \\
\text { neglasovne ekspresije: pomicanje krila kukaca }\end{array}$ \\
\hline D: stvaranje zvuka, maskiranje \\
\hline Priroda \\
\hline $\begin{array}{l}\text { S: rijeke i potoci, valovi, plima i oseka, ekscitacija vegetacije } \\
\text { primjerice: šuštanje lišća, padanje drveća... }\end{array}$ \\
\hline $\begin{array}{l}\text { D: stvaranje zvuka, maskiranje, širenje zvuka, apsorpcija, } \\
\text { refleksija, refrakcija, difuzija, difrakcija }\end{array}$ \\
\hline Teren \\
\hline S: barijere, nasipi, brane \\
\hline $\begin{array}{l}\text { D: stvaranje zvuka, širenje zvuka, apsorpcija, refleksija, } \\
\text { refrakcija, difuzija, difrakcija }\end{array}$ \\
\hline \hline
\end{tabular}

Legenda: S - zvučni izvori ili akustičke komponente; D - izravni akustički učinci.

Najčešća podjela zvučnih okolina je s obzirom na okoliš pa se može razlikovati:

a) prirodna zvučna okolina (primjerice morska, šumska zvučna okolina...)

b) seoska (ruralna) zvučna okolina

c) gradska (urbana) zvučna okolina.

S obzirom na način i stil današnjeg života, može se zaključiti da se gradska zvučna okolina najviše istražuje i najbrže mijenja. Gradska zvučna okolina obuhvaća sve tri aktivne komponente koje opisuju zvučne okoline, ali je ipak najviše prisutna antrofonija, odnosno zvukovi koje generiraju razne ljudske aktivnosti. Gledajući kroz povijest, nakon industrijske i električne revolucije izgled i zvučna slika grada su se iznimno promi- jenili. Danas se događa isto, ali kao posljedica ubrzane gradnje i prenapučenosti gradova. Jedan od najvećih problema u gradu je postala buka, a najveći izvor te buke je promet (Kull, 2006.). S druge strane, istraživanja pokazuju da se ljudski sluh, tj. mozak nakon nekog vremena prilagođava određenoj zvučnoj sredini iako je ona uhu izrazito neugodna. Iz tog razloga nameću se sljedeća pitanja:

1. Što se događa ako se u našoj „svakodnevnoj" zvučnoj okolini pojavi zvuk koji naš mozak ne percipira kao dio te zvučne okoline? (primjerice čovjek sjedi u parku, sunce sja, djeca se igraju, vrište i smiju se, a zatim u određenom trenutku on čuje sirenu vozila hitne pomoći...)

2. Koliko će nas zvuk koji "ne pripada" toj okolini uznemiriti te koliko će utjecati na naše općenito psihofizičko stanje i koncentraciju?

3. Koliko će nam trebati vremena da se naviknemo na taj ometajući zvuk i prestanemo ga percipirati?

4. Možemo li pokušati maskirati takve ometajuće zvukove ugodnima?

Zvučne okoline obično se snimaju soundwalk metodom (Semidor, 2006.). U soundwalk metodi se koristi snimač i par binauralnih mikrofona koje šetač odnosno snimatelj stavlja u uši. Snimatelj zatim, kao što govori naziv, kreće „u šetnju" kroz određenu okolinu. Snimatelj mora paziti na svoje disanje, a ovakva vrsta snimanja obavlja se uobičajeno po lijepom i sunčanom vremenu, izuzev ako se želi snimiti određena prirodna pojava, primjerice kiša. Snimanje se obavlja u visini šetača (jer su binauralni mikrofoni u ušima šetača) tako da su snimljeni signali što sličniji signalima koje čuju ljudi u toj zvučnoj okolini.

Uz soundwalk metodu kao sredstvo snimanja, iako nije propisano nijednom akustičkom normom, istraživači često provode analizu snimljenih zvučnih okolina uz pomoć upitnika. Koncept upitnika, kojem je svrha detaljna analiza od strane slušatelja, nije jasno definiran već je podložan individualnoj interpretaciji ovisnoj opet o potrebama istraživanja (Genuit, Bray, 2006., Kull, 2006.). 


\section{ODABRANE ZVUČNE OKOLINE RADNIH SREDINA}

Svaki grad ima svoju jedinstvenu zvučnu okolinu kao cjelina, a naravno da i svaki njegov manji dio ima specifičnu jedinstvenu zvučnu okolinu. $\mathrm{Na}$ području grada Zagreba odabrane su četiri radne sredine i snimljene su njihove zvučne okoline: dječji vrtić, prometnica Ljubljanska avenija, industrijska hala i trgovački centar (Suhanek et al., 2010.). Zvučne okoline snimljene su soundwalk metodom. Ove zvučne okoline odabrane su jer prema mišljenju autora predstavljaju stresne radne okoline, ali i vrlo različite zvučne okoline po svom spektralnom sastavu, glasnoći te brzini porasta naglih i neočekivanih promjena u glasnoći.

Sve četiri radne zvučne okoline snimljene su soundwalk metodom, koristeći M-AUDIO (http:// www.m-audio.com/) snimač i par binauranih mikrofona s frekvencijom uzorkovanja $48 \mathrm{kHz}$ i 16-bitnom kvantizacijom. Srednja razina zvučnog tlaka svih snimljenih zvučnih okolina je 50 dBA (+/-1dB). U svrhu zadržavanja jednake vrijednosti srednje razine zvučnog tlaka provedena je korekcija razine signala kompletnih snimljenih zvučnih okolina.

Snimke zvučnih okolina u ovoj studiji vrlo često bile su dulje od 45 minuta. Međutim, za samo ispitivanje, iz svake je izabran dio koji je bogat naglim i neočekivanim promjenama u glasnoći u trajanju od deset minuta. Deset minuta je odabrano kao kompromis između toga da se ispitanici adaptiraju i "užive" u određenu zvučnu okolinu, ali i da se ne dogodi zamor samom zvučnom okolinom.

\section{Radna okolina dječji vrtić}

Prva snimljena radna okolina je dječji vrtić, smješten u zapadnom djelu grada (slika 1). Snimatelj je sjedio na klupi sat vremena dok se veća skupina djece igrala. Vrtić je opremljen tipičnim dječjim igračkama: ljuljačkama, klackalicama, malim golovima, toboganom i pješčanikom. Iz te snimljene zvučne okoline uzet je uzorak u trajanju od deset minuta koji obuhvaća zvukove tipične za djecu: njihov plač, vriska, deranje, zvukovi koji dolaze od dječjih igrački u vrtiću npr. ljuljačke te zvuk govora odgajateljice iz vrtića.
Spektrogrami zvučnih okolina dobiveni su korištenjem Hanningovog prozora (bez preklapanja) čija je duljina $371 \mathrm{~ms}$ te frekvencijska rezolucija 1,3 Hz. Slika 2 prikazuje deset minuta spektrograma snimljene zvučne okoline dječjeg vrtića.

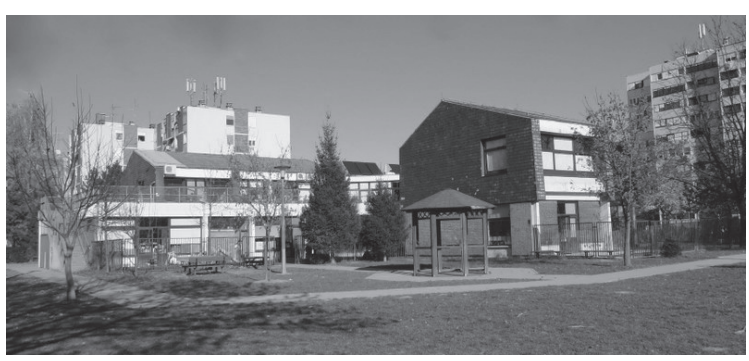

Slika 1. Dječji vrtić

Figure 1. Kindergarten

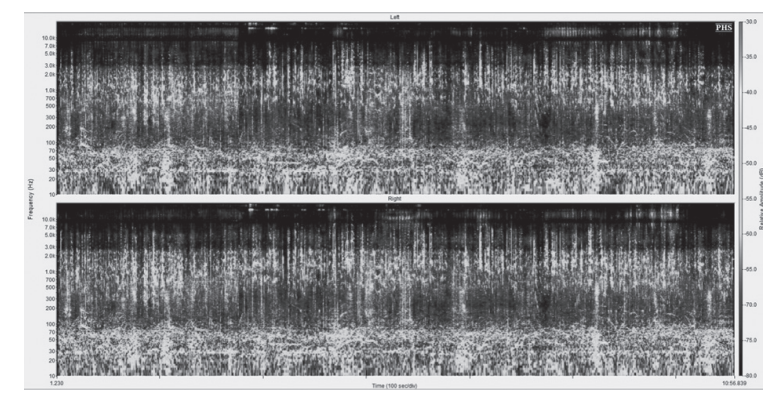

Slika 2. Spektrogram radne okoline dječjeg vrtića

Figure 2. Spectrogram of a kindergarten work environment

Spektrogram zvučne okoline dječjeg vrtića ima vrlo širok frekvencijski raspon, proteže se i iznad $10 \mathrm{kHz}$, s kratkim promjenama u razini zvučnog tlaka koje su do 20 dB glasnije od ujednačenog dijela snimke.

\section{Radna okolina Ljubljanska avenija}

Sljedeća snimljena radna okolina je Ljubljanska avenija koja se proteže od centra Zagreba do zapadnog izlaza iz grada (slika 3). Avenija ima tri prometne trake u oba smjera te je jedna od najprometnijih zagrebačkih prometnica. S obje strane avenije, u prosjeku 50 metara od ceste nalaze se stambene zgrade, poslovni prostori i trgovački centri. Tijekom čitavog dana, pa čak i noći, promet je na Aveniji vrlo gust. Zvučna okolina je snimljena tijekom šetnje (oko dva kilometra) uz Aveniju te uključuje stajanje na semaforu i čekanje na zeleno svjetlo za pješake te vraćanje na početnu poziciju snimanja, ali u suprotnom smjeru. Ukupno trajanje snimke je 45 minuta. Snim- 
ka uključuje zvukove automobila i teretnih vozila koji prolaze, trube automobila, zvučni signal semafora za slijepe osobe itd. Slika 4. prikazuje spektrogram zvučne okoline Ljubljanske avenije u trajanju od deset minuta.

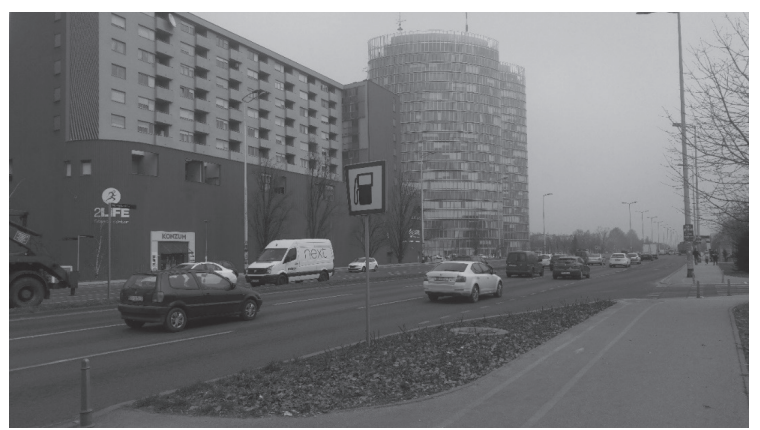

Slika 3. Ljubljanska avenija

Figure 3. Ljubljanska Avenue

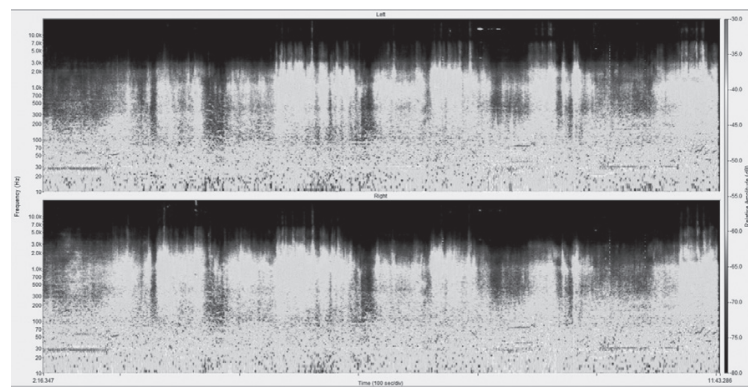

Slika 4. Spektrogram radne okoline Ljubljanske avenije

Figure 4. Spectrogram of Ljubljanska Avenue work environment

Usporedbom frekvencijskog spektra dječjeg vrtića i Ljubljanske avenije vidi se da je spektar Ljubljanske avenije uži i koncentriran na frekvencijama nižim od $3 \mathrm{kHz}$. Nagle promjene u glasnoći ovdje nisu toliko velike te odgovaraju uglavnom glasnijim automobilima i teretnim vozilima koji prolaze po Aveniji.

\section{Radna okolina industrijska hala}

Treća radna okolina je TŽV Gredelj, tvrtka koja se bavi proizvodnjom lokomotiva i željezničkih vagona (slika 5). Osoba koja je snimala zvučnu okolinu sjedila je sat vremena u sredini industrijske hale TŽV Gredelj tijekom uobičajenog radnog dana. Zvučna okolina obuhvaća zvukove različitih alata, brusilica i bušilica te čekića koji udara u metalne predmete.

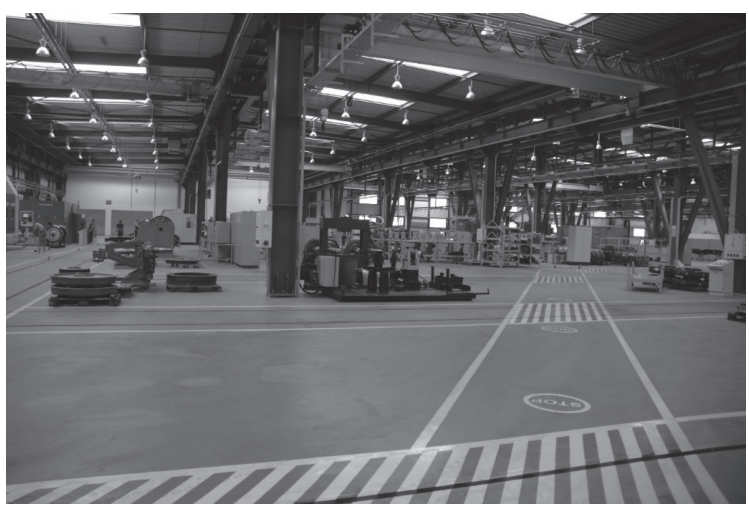

Slika 5. Industrijska hala

Figure 5. Industrial plant

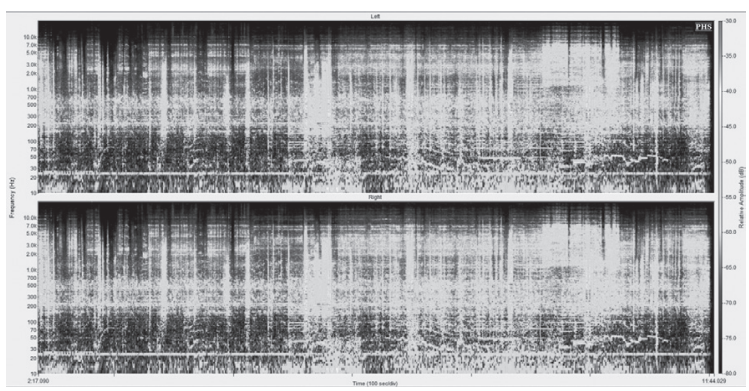

Slika 6. Spektrogram radne okoline industrijske hale

Figure 6. Spectrogram of an industrial plant work environment

Na spektrogramu zvučne okoline industrijske hale (slika 6) vidljivo je koliko su glasni zvukovi specifični za tu okolinu. Frekvencijski spektar je širok te prelazi na dijelovima $10 \mathrm{kHz}$, s kratkim promjenama u razini zvučnog tlaka do čak $30 \mathrm{~dB}$ iznad prosjeka.

\section{Radna okolina trgovački centar}

Četvrta snimljena radna okolina je trgovački centar (slika 7). Spektrogram zvučne okoline trgovački centar ima relativno širok frekvencijski raspon, proteže se i do $10 \mathrm{kHz}$, s nekoliko kratkih promjena u razini zvučnog tlaka koje su do $15 \mathrm{~dB}$ glasnije od ujednačenog dijela snimke (slika 8). 


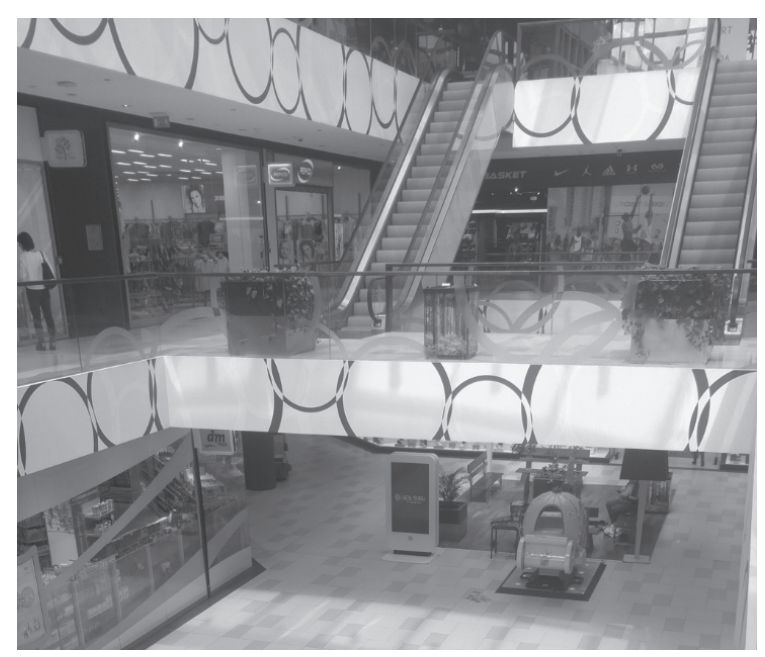

Slika 7. Trgovački centar

Figure 7. Shopping centre

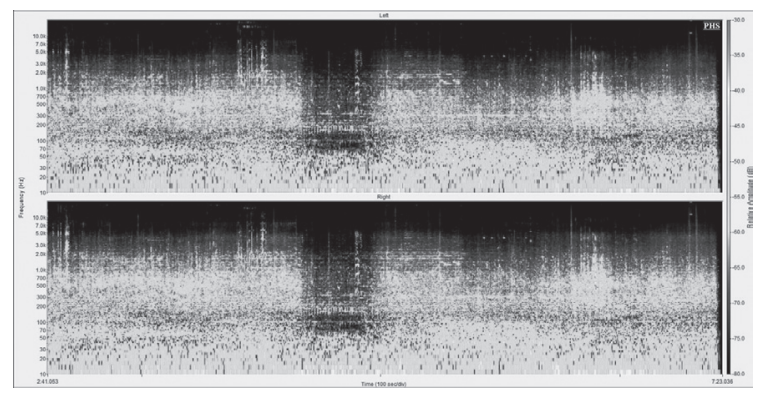

Slika 8. Spektrogram zvučne okoline trgovačkog centra

Figure 8. Spectrogram of the sound environment of a shopping centre

\section{SUBJEKTIVNI PARAMETRI ZA VREDNOVANJE ZVUČNIH OKOLINA}

Subjektivna ispitivanja smatraju se temeljnim dijelom procesa klasifikacije i vrednovanja zvučnih okolina jer čovjekovo mišljenje i percepcija određene zvučne okoline u konačnici formira dojam zvučne okoline - na temelju kojeg se onda može provesti akustička karakterizacija zvučnih okolina.

Opisu zvučne okoline pomoću subjektivnih parametara potrebno je pristupiti imajući u vidu njezinu multidisciplinarnost. Potrebno je definirati veći broj subjektivnih parametara kojima je moguće učinkovito opisati i definirati zvučnu okolinu imajući u vidu da odabir konkretnih parametara ovisi o svrsi samog istraživanja (Schul-
te-Fortkamp, Fiebig, 2006., Nilsson, Berglund, 2006., Berglund, Nilsson, 2006.).

\section{Metodologija korištena u istraživanju}

U ovom istraživanju korištene su metode koje su već prihvaćene u studijama i istraživanjima o zvučnim okolinama odnosno upitnici koji služe uglavnom kao opisna mjera ugodnosti pojedine zvučne okoline (Raimbault, 2006., Kang, Zang, 2010.) kao i prihvaćene metode u psihologiji (Bujas, 1981., Milas, 2009.). Broj ispitanika u studiji je 50, a zastupljenost oba spola je jednaka. Prosječna dob ispitanika je 24 godine. Redoslijed preslušavanja zvučnih okolina bio je jednak za sve slušatelje. U ovom istraživanju prvo se slušala snimka dječjeg vrtića, zatim Ljubljanske avenije, industrijske hale i na kraju trgovačkog centra. Sam redoslijed slušanja odabran je nasumično, ali je jednak za sve ispitanike te je važno istaknuti da postoji vremenski razmak od minimalno sedam dana između testiranja kako bi se izbjegao zamor i iritacija slušatelja. Slušatelji su dobili jasne upute u vezi s upitnikom, ali nisu bili upoznati s time što će slušati niti koji su cilj i hipoteza istraživanja. Ispitivanje je provedeno u slušaonici Zavoda za elektroakustiku na Fakultetu elektrotehnike i računarstva Sveučilišta u Zagrebu.

Metodologija je nadopunjena zadatkom koji slušatelji rješavaju tijekom reprodukcije zvučne okoline jer sam upitnik ne daje dovoljno jasnu mjeru razine distrakcije slušatelja što je jedan od glavnih ciljeva ovog istraživanja. Zadatak je zamišljen kao svojevrsna nadopuna upitnika kako bi se dobila što točnija klasifikacija zvučnih okolina te razina distrakcije slušatelja naglim i neočekivanim promjenama u glasnoći neke radne okoline.

\section{Zadatak}

Uz upitnik u ovom istraživanju korišten je zadatak u obliku programirane igre koji su slušatelji rješavali tijekom reprodukcije snimke zvučne okoline. Zadatak ima funkciju zamijeniti svakodnevni posao koji zahtijeva određenu razinu koncentracije, te generirati informacije o utjecaju radnih zvučnih okolina na slušatelja odnosno kvantificirati razinu distrakcije.

Zadatak koji ispitanici izvršavaju dok slušaju određenu zvučnu okolinu najsličniji je dječjoj igri 
Memory. Igra je programirana u Matlabu (http:// www.mathworks.com/products/matlabx. Prilikom pokretanja same igre slušatelju se preko slušalica reproducira zvučna okolina. Igra se sastoji od dva reda po pet kartica. Na karticama su simboli "X"

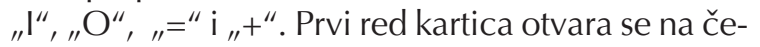
tiri sekunde i cilj ispitanika je zapamtiti redoslijed simbola u prvom redu. Prvi red se zatim zatvara i otvara se drugi red u kojem se nalazi pet kartica s istim simbolima, ali s drugačijim redoslijedom. Ispitanik klikom miša mora ponoviti redoslijed simbola na karticama koji se pojavio u prvom redu. Slušatelj ima sedam sekundi za ponavljanje zadanog redoslijeda kartica i zatim dvije sekunde

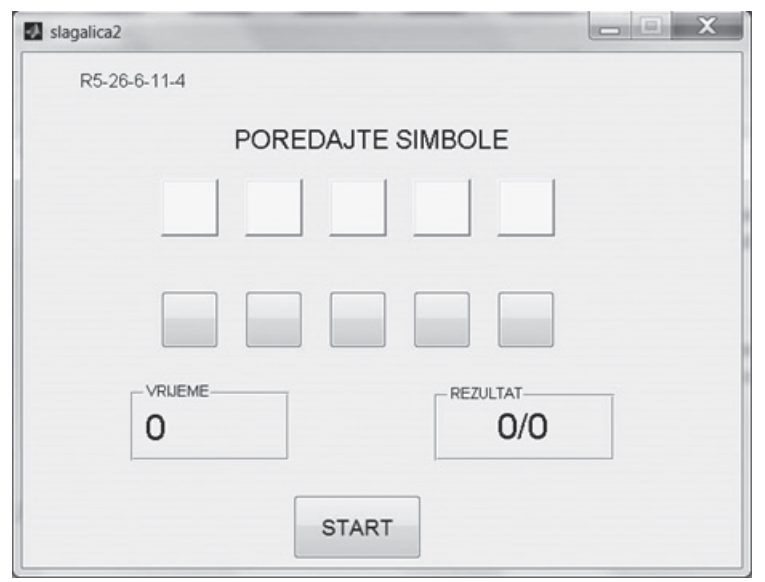

pauze prije generiranja novog redoslijeda kartica. Tijekom snimke zvučne okoline igra neprekidno generira novi slijed kartica. Ako ispitanik pogriješi, igra odmah generira novi slijed kartica. Igra je programirana na način da prati uspješnost i vrijeme poteza ispitanika. Primjerice, u četrdeset i petoj sekundi snimke ispitanik je uspio ponoviti redoslijed tri od pet kartica odnosno njegova uspješnost je 3/5 ili $60 \%$. Igra pohranjuje podatke o svakom igraču odnosno slušatelju pa se može promatrati koji zvukovi unutar same zvučne okoline su ometajući za ispitanika i koliko je ispitanik uspješan u igrici odnosno drugim riječima u ispunjavanju svakodnevnog posla.

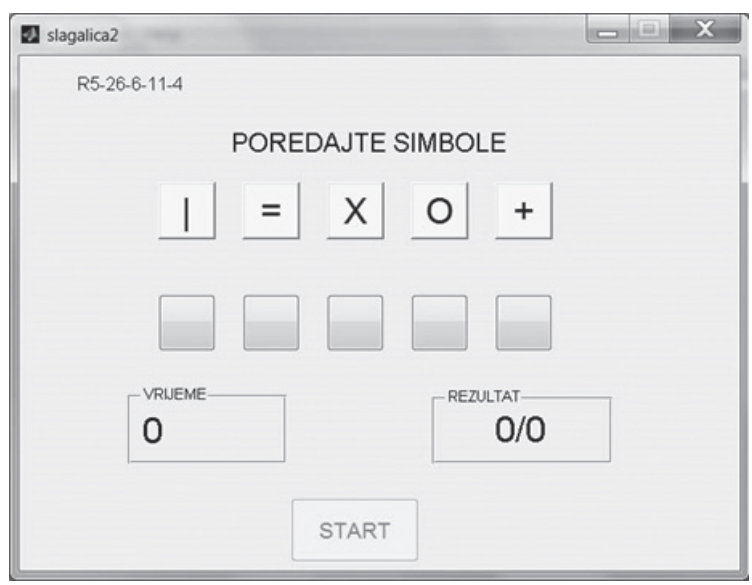

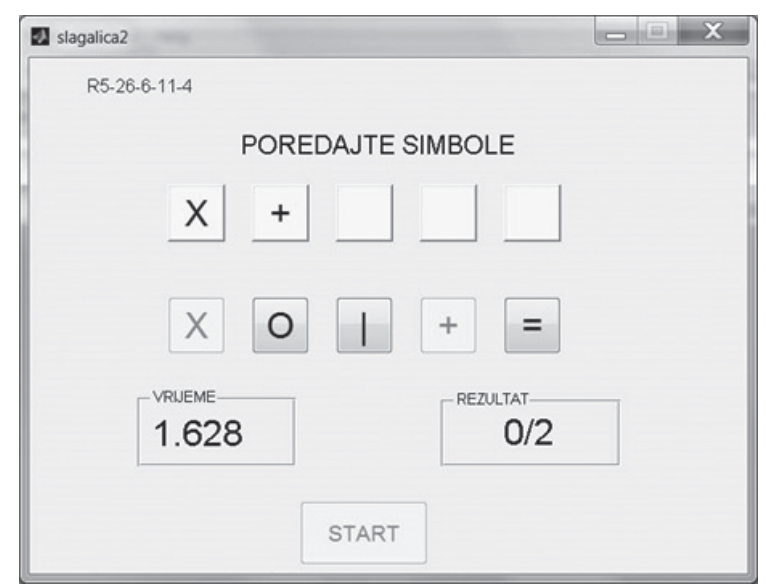

Slika 9. Sučelje igre na računalu u koracima: početak (zatvorene kartice sa simbolima), otvoreni prvi red (raspored simbola koji treba zapamtiti i ponoviti), otvoreni drugi red (isti simboli, ali na drugim mjestima - klikom miša mora se ponoviti redoslijed simbola u prvom redu)

Figure 9. Computer game interface: start (closed symbol cards), open first row (order of symbols to be memorised and repeated), open second row (same symbols but in different places - after a click of the mouse the order of the symbols in the first row must be repeated) 
Dakle, u prvom dijelu istraživanja slušatelji su rješavali interaktivnu igru na računalu, a zatim popunjavali upitnik posebno kreiran za svaku radnu okolinu. Tijekom rješavanja igre i kasnije tijekom popunjavanja upitnika slušateljima se cijelo vrijeme na slušalicama reproducira pripadajuća snimka radne zvučne okoline. Trajanje snimke je ograničeno na deset minuta, pa samim time i vrijeme izvršavanja zadatka je deset minuta. Ovisi o samom ispitaniku, njegovoj koncentraciji i brzini koliko je sljedova kartica uspio ponoviti. Međutim, potrebno je istaknuti da su nakon odigrane igre odnosno nakon zadatka, tijekom popunjavanja upitnika, slušatelji "imali slobodu" reproducirati određenu zvučnu okolinu koliko god su puta to smatrali potrebnim.

\section{Koncept upitnika}

Upitnik korišten u ovom istraživanju obuhvaća općenite podatke: ime i prezime te dob i spol. Postavljeno je samo jedno pitanje: "Koliko Vas iritiraju vanjski zvukovi u Vašoj okolini? (primjer: čitanje knjige uz glazbu) ". Ponuđeni odgovori su "nimalo" i "izrazito", a između njih je skala od sedam stupnjeva (slika 10).

\begin{tabular}{llllllll}
\hline nimalo & & & & & & izrazito \\
$\square \quad \square \quad \square \quad \square \quad \square \quad \square \quad \square$ & \\
\hline
\end{tabular}

Slika 10. Metoda stupnjevanog ocjenjivanja korištena u ovom istraživanju

Figure 10. Grading assessment method used in the study

Drugi dio upitnika specifičan je za svaku zvučnu okolinu. Postavljena su dva pitanja slušateljima: "Koji od ponuđenih zvukova na snimci Vas je najviše zasmetao?" i "Zbog čega Vas smeta odabrani zvuk?". Na prvo pitanje slušateljima su ponuđeni odgovori ovisno o zvučnoj okolini. Međutim, vrlo bitno je istaknuti da su u ponuđenim odgovorima navedeni svi zvukovi koji se pojavljuju u određenoj zvučnoj okolini tako da je izbjegnut moguć neželjeni utjecaj na slušatelje. Također je ostavljena mogućnost da je slušatelja zasmetalo sve kao i da ga u određenoj zvučnoj okolini nije smetalo ništa.

Ponuđeni odgovori na pitanje: "Zašto Vas odabrani zvuk najviše smeta?" jednaki su za sve zvučne okoline: glasnoća, pojavljivanje izrazito niskih tonova, pojavljivanje izrazito visokih tonova, učestalost pojavljivanja, trajanje i "neuklapanje" u postojeću zvučnu okolinu.

Za dječji vrtić na pitanje: "Koji od ponuđenih zvukova na snimci Vas je najviše zasmetao?" ponuđeni su odgovori: vriska djece, zvuk ljuljačke, dječji plač, odgajateljica koja doziva djecu, sve navedeno i ništa me nije dekoncentriralo.

Za Ljubljansku aveniju slušatelji su imali izbor između: sirena vozila Hitne pomoći, zvuk semafora, automobili, svega navedenog i ništa me nije dekoncentriralo.

Za industrijsku halu ponuđeni odgovori su: brusilice, čekići, glazba s radija, sve navedeno i ništa me nije dekoncentriralo.

Za zvučnu okolinu trgovačkog centra na pitanje "Koji od ponuđenih zvukova na snimci Vas je najviše zasmetao?" ponuđeni su odgovori: plač djeteta, vriska djeteta, razgovor u pozadini, glazba u pozadini, sve navedeno i ništa me nije dekoncentriralo.

\section{ANALIZA REZULTATA SUBJEKTIVNIH ISPITIVANJA}

Tablica 2. prikazuje prosječni rezultat ispitanika u sve četiri radne okoline. Vidljivo je da se radne zvučne okoline mogu "rangirati" prema uspješnosti ispitanika u izvršavanju zadatka redom: Ljubljanska avenija, trgovački centar, industrijska hala i dječji vrtić.

\section{Tablica 2.Prosječni rezultat ispitanika za sve četiri zvučne okoline}

Table 2. Average results for all four sound environments

\begin{tabular}{||c|c||}
\hline Zvučna okolina & Prosječni rezultat \\
\hline Dječji vrtić & 0,86 \\
\hline Ljubljanska avenija & 0,93 \\
\hline Industrijska hala & 0,87 \\
\hline Trgovački centar & 0,89 \\
\hline
\end{tabular}

Kao što je već objašnjeno u prijašnjem poglavlju, drugi dio upitnika je specifičan za svaku zvučnu okolinu. Postavljena su dva pitanja ispitanicima: "Koji od ponuđenih zvukova na snimci Vas je najviše zasmetao?" i "Zbog čega Vas smeta 
odabrani zvuk?". Iznimno je bitno istaknuti da su u ponuđenim odgovorima navedeni svi zvukovi koji se pojavljuju u određenoj zvučnoj okolini tako da je izbjegnut moguć neželjeni utjecaj na ispitanike. Također je ostavljena mogućnost da je ispitanika sve zasmetalo kao i da ga, u određenoj zvučnoj okolini, nije smetalo ništa.

Iz rezultata (slika 11. za dječji park, slika 12. za Ljubljansku aveniju, slika 13. za industrijsku halu i slika 14. za trgovački centar) je vidljivo da

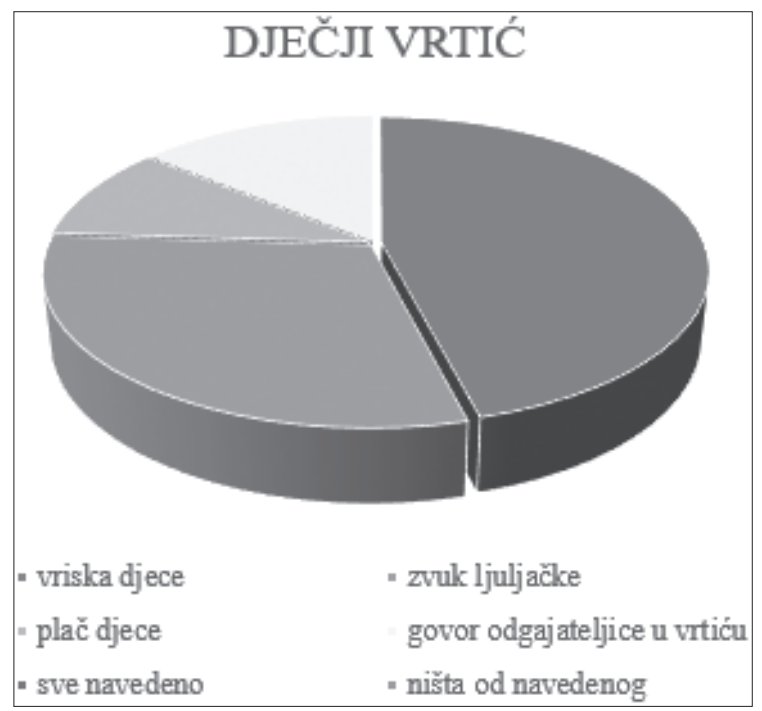

Slika 11. Razlozi ometanja i iritacije slušatelja za dječji vrtić

Figure 11. Disturbing factors and sources of irritation experienced by listeners in kindergarten

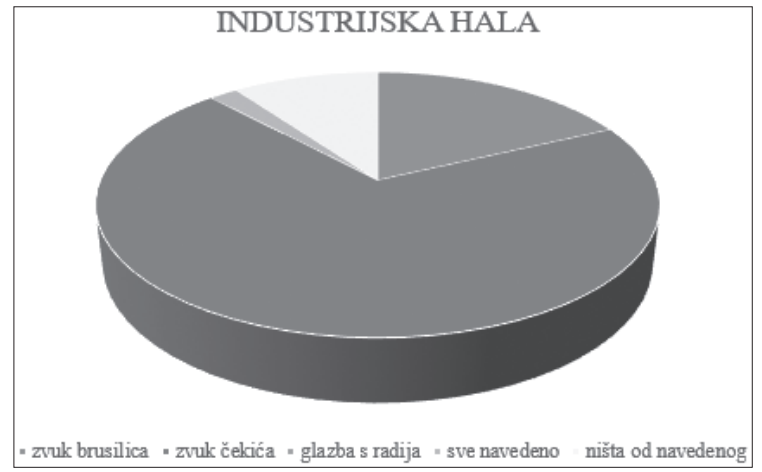

Slika 13. Razlozi ometanja i iritacije slušatelja za industrijsku halu

Figure 13. Disturbing factors and sources of irritation experienced by listeners in an industrial plant je ispitanike u radnoj okolini dječji vrtić najviše smetala vriska djece. Za Ljubljansku aveniju slušateljima je najiritabilniji zvuk, zvuk automobila. Kod radne okoline industrijska hala ispitanike je najviše zasmetao zvuk čekića. Za zvučnu okolinu trgovački centar, najčešći odgovor iritacije je plač djece.

Na drugo pitanje u upitniku "Zbog čega Vas smeta odabrani zvuk?" ispitanici su također imali ponuđene odgovore odnosno "razloge ometanja":

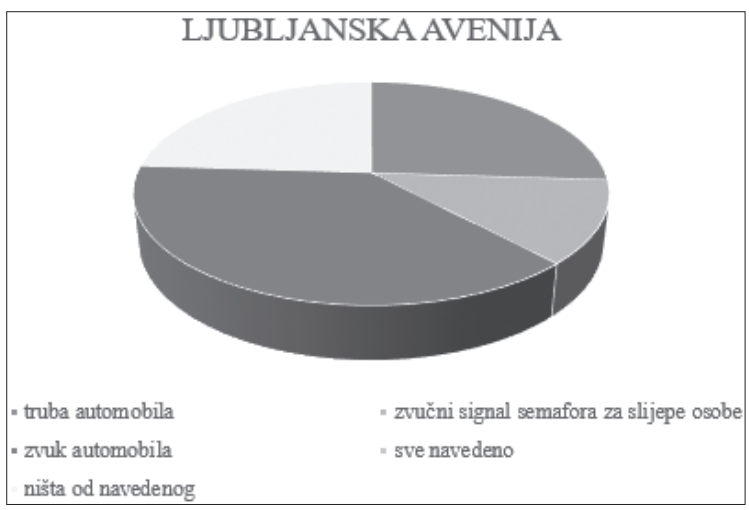

Slika 12. Razlozi ometanja i iritacije slušatelja za Ljubljansku aveniju

Figure 12. Disturbing factors and sources of irritation experienced by listeners at Ljubljanska Avenue

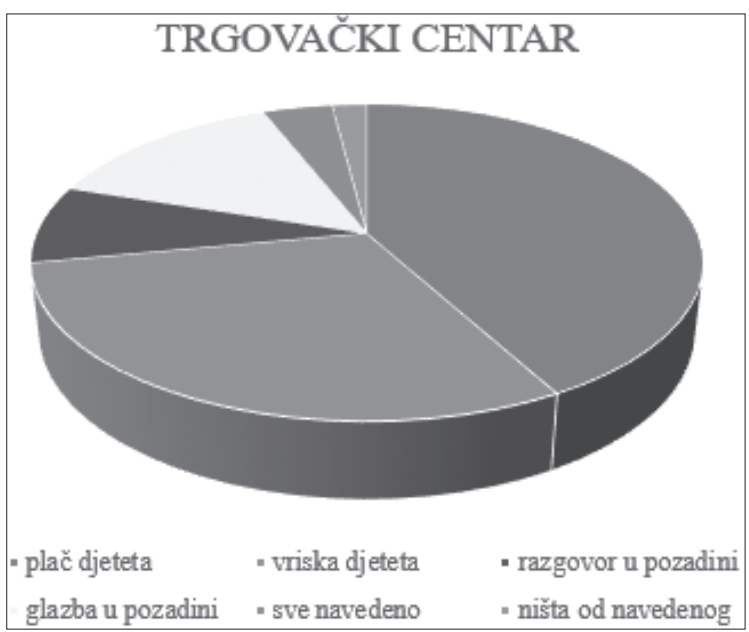

Slika 14. Razlozi ometanja i iritacije slušatelja za trgovački centar

Figure 14. Disturbing factors and sources of irritation experienced by listeners in a shopping centre 
glasnoća, prisutnost niskih tonova, prisutnost visokih tonova, učestalost pojavljivanja ometajućeg zvuka, trajanje, zvuk je neuobičajen za određenu zvučnu okolinu te sve navedeno. Ako je ispitanik na prijašnje pitanje "Koji od ponuđenih zvukova na snimci Vas je najviše zasmetao?" odgovorio negativno, odnosno da ga nije zasmetao nijedan zvuk, na sljedeće pitanje nije morao odgovarati. Dakle, rezultate ispitanika koje je određeni zvuk zasmetao prikazuje Tablica 4. za četiri radne okoline.

Tablica 4. „Razlozi ometanja“ određenim zvukom u pojedinoj radnoj okolini

Table 4. Causes of disturbance by certain sounds in different work environments

\begin{tabular}{|c|c|c|c|c|c|c|}
\hline \multicolumn{7}{|l|}{ Dječji vrtić } \\
\hline & glasnoća & visoki tonovi & učestalost & trajanje & \multicolumn{2}{|c|}{ neočekivanost } \\
\hline vriska djece & $27 \%$ & $42 \%$ & $8 \%$ & & \multicolumn{2}{|c|}{$23 \%$} \\
\hline zvuk ljuljačke & $6 \%$ & $38 \%$ & $31 \%$ & $13 \%$ & \multicolumn{2}{|c|}{$12 \%$} \\
\hline plač djece & $16 \%$ & $34 \%$ & & & \multicolumn{2}{|c|}{$50 \%$} \\
\hline govor tete u vrtiću & $87 \%$ & & & & \multicolumn{2}{|c|}{$13 \%$} \\
\hline sve navedeno & $100 \%$ & & & & & \\
\hline \multicolumn{7}{|l|}{ Ljubljanska avenija } \\
\hline & glasnoća & visoki tonovi & učestalost & trajanje & \multicolumn{2}{|c|}{ neočekivanost } \\
\hline truba automobila & & & & & \multicolumn{2}{|c|}{$100 \%$} \\
\hline $\begin{array}{l}\text { zvučni signal } \\
\text { semafora }\end{array}$ & & & $20 \%$ & & \multicolumn{2}{|c|}{$80 \%$} \\
\hline zvuk automobila & $52 \%$ & & $35 \%$ & $13 \%$ & & \\
\hline \multicolumn{7}{|l|}{ sve navedeno } \\
\hline \multicolumn{7}{|l|}{ Industrijska hala } \\
\hline & glasnoća & visoki tonovi & učestalost & trajanje & \multicolumn{2}{|c|}{ neočekivanost } \\
\hline zvuk brusilica & $37 \%$ & $37 \%$ & $26 \%$ & & & \\
\hline zvuk čekića & $68 \%$ & $6 \%$ & $3 \%$ & & \multicolumn{2}{|c|}{$23 \%$} \\
\hline \multicolumn{7}{|l|}{ glazba s radija } \\
\hline sve navedeno & $100 \%$ & & & & & \\
\hline \multicolumn{7}{|l|}{ Trgovački centar } \\
\hline & glasnoća & niski tonovi & visoki tonovi & učestalost & trajanje & neočekivanost \\
\hline plač djeteta & $21 \%$ & $3 \%$ & $24 \%$ & $10 \%$ & $7 \%$ & $35 \%$ \\
\hline vriska djeteta & $18 \%$ & $5 \%$ & $27 \%$ & $9 \%$ & $9 \%$ & $32 \%$ \\
\hline razgovor u pozadini & & & $33 \%$ & $50 \%$ & $17 \%$ & \\
\hline glazba u pozadini & $23 \%$ & $8 \%$ & $8 \%$ & $15 \%$ & $8 \%$ & $38 \%$ \\
\hline sve navedeno & & & & $100 \%$ & & \\
\hline
\end{tabular}


Analizom rezultata prikazanih ovim tablicama mogu se izvesti sljedeći zaključci. Za radnu okolinu dječji vrtić najiritabilniji zvukovi su vriska djece i zvuk ljuljačke. Za vrisku djece razlog ometanja su visoki tonovi, dok kod zvuka ljuljačke ispitanike su smetali visoki tonovi, ali i učestalost pojavljivanja tog zvuka.

Kod radne okoline Ljubljanska avenija jedini zvuk koji je osjetno zasmetao slušatelje je zvuk automobila zbog svoje glasnoće.

U slučaju radne okoline industrijska hala razlog ometanja zvukom čekića je njegova glasnoća.

Kod radne okoline trgovački centar plač djeteta i vriska djeteta su ispitanike smetali zbog prisutnosti visokih tonova $\mathrm{i}$ jer ih nisu očekivali, razgovor u pozadini zbog učestalosti pojavljivanja, a glazba u pozadini zbog glasnoće i neočekivanosti.

Iz analize se može zaključiti da su najčešći razlozi ometanja koje ispitanici daju glasnoća, visoki tonovi i učestalost pojavljivanja određenog zvuka.

\section{ZAKLJUČAK}

Zvučne okoline kao dio akustike su vrlo široko područje za istraživanje i zahtijevaju multidisciplinaran pristup. Jedan od glavnih ciljeva je provesti vrednovanje radnih zvučnih okolina s obzirom na ljudsku percepciju i koncentraciju, u ovisnosti o objektivnim i subjektivnim parametrima. Istraživanje je provedeno za četiri radne okoline (dječji vrtić, Ljubljanska avenija, industrijska hala i trgovački centar) koje su odabrane zbog svoje karakterističnosti za bilo koju urbanu sredinu, a s druge strane zbog različitosti s obzirom na akustičke karakteristike kao primjerice spektralni sastav, glasnoća, brzina porasta naglih i neočekivanih promjena u glasnoći i slično. Također, ako se odabrane zvučne okoline promatraju iz aspekta radnih okolina, može se zaključiti da ih većina ljudi smatra stresnim radnim sredinama odnosno, stresnim zaposlenjima.

Zvučne okoline su snimljene soundwalk metodom.

U suradnji sa psihologom $\mathrm{u}$ ovom radu prilikom ispitivanja slušatelja primijenjene su metodologije prihvaćene u psihologiji za istraživanja na živim subjektima.

Tijekom slušanja snimki radnih okolina slušatelji su izvršavali zadatak koji je imao funkciju zamijeniti svakodnevni posao koji zahtijeva određenu razinu koncentracije (primjerice, u slučaju radne okoline trgovački centar zaposlenici moraju naplatiti kupljenu robu) te prema rezultatima izvršavanja zadatka dati podatke koliko slušatelje ometa određena radna zvučna okolina i pojedini njezini dijelovi.

Nakon slušanja snimki zvučnih okolina ispitanici su rješavali posebno kreiran upitnik koji sadrži dva pitanja: "Koji od ponuđenih zvukova na snimci Vas je najviše zasmetao?" i "Zbog čega Vas smeta odabrani zvuk?".

Konačno sintezom rezultata zadatka i upitnika moguće je rangirati radne zvučne okoline s obzirom na distrakciju odnosno ometanje ispitanika. Može se zaključiti da je najneugodnija radna okolina dječji vrtić, a zatim industrijska hala. Najmanje neugodna zvučna okolina je Ljubljanska avenija.

S obzirom na današnje vrijeme, ubrzani stil života i činjenice da većina ljudi najviše vremena provodi na poslu, krajnje je vrijeme početi razmišljati i o tome da se radne sredine učine što ugodnije zaposlenicima uzimajući u obzir čak i njihova akustička svojstva. Akustički ugodna radna sredina može svakako pridonijeti zadovoljstvu, a prema rezultatima ovog rada i uspješnosti te učinkovitosti svojih zaposlenika. Budući rad bit će fokusiran na moguće načine koji omogućuju radne okoline koje su okarakterizirane kao neugodne učiniti ugodnijima uz pomoć raznih akustičkih alata. 


\section{LITERATURA}

Berglund, B., Nilsson, M. E.: On a tool for measuring soundscape quality in urban residential areas, Acta Acustica united with Acustica, 92, 2006., 6, str. 938-944.

Bujas, Z.: Uvod u metode eksperimentalne psihologije, (Introduction to the methods of experimental psychology), Školska knjiga, Zagreb, 1981.

Genuit, K., Bray, W.: Soundscape measurement and analysis, Journal of the Acoustical Society of America, 119, 2006., str. 3260.

Kang, J., Zang, M.: Semantic differential analysis of the soundscape in urban public spaces, Building and Environment, 45, 2010., 1, str. 150-157.

Krause, B.: Anatomy of the Soundscapes Evolving Perspectives, Journal of the Acoustical Society of America, 56, 2008., str. 73-80.

Kull, C.R.: Soundscape measurements: Moving towards a standard, Journal of the Acoustical Society of America, 116, 2005., str. 1875.

Kull, C.R.: Natural and Urban Soundscapes - The Need for a Multi - Disciplinary Approach, Acta Acustica united with Acustica, 92, 2006., str. 898-902.

M Audio snimač, dostupno na: http://www.maudio.com/, pristupljeno: 10.12.2018.

Memory igra, dostupno na: http://www.mathworks.com/products/matlab/, pristupljeno: 10.12.2018.
Milas, G.: Istraživačke metode u psihologiji i drugim društvenim znanostima, (Research Methods in Psychology and other Social Sciences), Naklada Slap, 2009., Zagreb, str. 91-118., 153216.

Nilsson, M. E., Berglund, B.: Soundscape Quality in Suburban Green Areas and City Parks, Acta Acustica united with Acustica, 92, 2006., 6, str. 903-911.

Raimbault, M.: Qualitative Judgements of Urban Soundscapes: Questioning Questionnaires and Semantic Scales, Acta Acustica united with Acustica, 92, 2006., 6, str. 929-937.

Schafer, R. M.: Our Sonic Environment and the Soundscape: The Tuning of the World, Destiny Books, Vermont, 1994., str. 3-259.

Schulte-Fortkamp, B., Fiebig, A.: Soundscape Analysis in a Residential Area: An Evaluation of Noise and People's Mind, Acta Acustica united with Acustica, 92, 2006., 6, str. 875-880.

Semidor, C.: Listening to a City With the Soundwalk Method, Acta Acustica united with Acustica, 92, 2006., 6, str. 959-964.

Suhanek, M., Đurek, I., Jambrošić, K.: The soundscape of urban public places in Zagreb, Proceedings of 1st EAA - EuroRegio 2010., Ljubljana, 2010., str. 1-5. 


\section{A CASE STUDY OF DIFFERENT SOUND ENVIRONMENTS - A WAY TO A MORE PLEASANT AND MORE EFFICIENT WORK ENVIRONMENT}

SUMMARY: The concept of soundscape was introduced to modify and complement noise assessment and the effect of different sound environments on people. Soundscape research poses a somewhat different problem than the study of noise as such, for it is a more complex phenomenon that requires a multidisciplinary approach. Therefore, sound environments study is not a study of noise but of the conditions and causes, the level of perception and the effects on people. Any sound environment will be subjected to a substantial number of sound sources that affect ordinary human activities, people's concentration and mood. Most people today spend a great deal of time at work, so it would be desirable that their work environment is acoustically pleasant in order to ensure effective work and satisfaction of the workers. The paper discusses four sound environments: kindergarten, expressway, industrial plant, and shopping centre. These four have been selected for they are generally perceived as stressful for the employees.

Key words: rsoundscape, sound environment, soundwalk method, work environment, questionnaire, task 